\title{
Leaves of Ground Cherry (Physalis angulata L.) May Be Suitable in Alleviating Micronutrient Deficiency
}

\author{
A.A. Aliero ${ }^{1, *}$, H. Usman ${ }^{2}$ \\ ${ }^{1}$ Department of Biological Sciences, Usmanu Danfodiyo University, Nigeria \\ ${ }^{2}$ Department of Biological Sciences, Federal University, Nigeria
}

Copyright $\bigcirc 2016$ by authors, all rights reserved. Authors agree that this article remains permanently open access under the terms of the Creative Commons Attribution License 4.0 International License

\begin{abstract}
Physalis angulata (L.) is an annual herbaceous neglected underutilized species used as vegetable and in herbal medicine for the treatment of infectious diseases in Nigeria. This study evaluated proximate, minerals and amino acids content of $P$. angulata leaves and fruits using standard methods with the view to understanding its nutritional potential. The leaves and fruits had crude protein content of 27.80 and $10.97 \%$ respectively. The fruits had the highest sodium content of 689.48 $\mathrm{mg} / 100 \mathrm{~g}$ while, the leaves had the highest content of manganese with $21.60 \mathrm{mg} / 100 \mathrm{~g}$. The result of amino acid analysis indicates that the leaves had isoleucine, valine, phenylalanine + Tyrosine contents of 3.04, 4.36 and 6.38 $\mathrm{g} / 100 \mathrm{~g}$ protein respectively, which are within WHO ideal protein standard. These components are however low in fruits except phenylalanine + Tyrosine and leucine with 5.22 and $5.16 \mathrm{~g} / 100 \mathrm{~g}$ protein respectively. Concentration of phytate was $6.91 \mathrm{mg} / 100 \mathrm{~g}$ in the leaves and $8.59 \mathrm{mg} / 100 \mathrm{~g}$ in the fruits. Similarly, oxalate content was 2.74 and 3.21 $\mathrm{mg} / 100 \mathrm{~g}$ in the leaves and fruits respectively. Prediction of minerals bioavailability indicates that the concentration of oxalate and phytate may interfere with bioavailability of calcium, zinc and iron. The concentration of [Phytate] / [Zn] in the leaves was comparatively low (5.32) which is an indication for its potential into food-based strategy to alleviate zinc malnutrition. The result of this study indicate that leaves of $P$. angulata contain substantial amounts of nutrient and suggest its potential as a source of nutrients that could be useful in alleviating micronutrient deficiency.
\end{abstract}

Keywords Physalis angulata, Micronutrient, Amino Acids, Bioavailability

\section{Introduction}

The World Health Organization [1] reported that chronic under nutrition affects over 200 million people or $42 \%$ of the population in Sub - Saharan Africa. Malnutrition affects millions people all over the world especially in developing countries. Under nutrition for the poor people and over nutrition for the rich segment of the population are two parallel forms of malnutrition affecting these nations [2]. Over nutrition is associated with nutritional transition which is due to urbanization as such the city dwellers consume mostly refined and junk foods $[3,4,[5]$. This transition leads to increased risk of non - communicable diseases such as diabetes, hypertension, obesity, cancer and cardiovascular diseases which were previously known to be the diseases of the developed nations. World Health Organisation (WHO) projected that the percentage of the diabetes in developing countries may increase to more than two fold from 115 million in 2000 to 284 million (about $250 \%$ increment) in 2030 [6]. To tackle the problem of malnutrition, consumption of fruits and vegetables is a promising solution [7].Literature has shown that there are about 115 edible wild plants species found in Africa which are routinely used to supply both the macro and micro nutrients [8]. Nutritional composition of plant food is affected by environmental conditions and genetic composition among other factors. Investigation on the nutritional content of plant species within a given locality is imperative so as to document its nutritional and anti-nutritional contents with the aim of utilizing the plant as sourceof nutrient that could be useful in addressing mineral deficiencies.

Physalis angulata (L.) is an annual, herbaceous plant which belongs to the family solanaceae which isa native to tropical America and now widely distributed pan tropically as weed. It is an effective stimulant for the immune system and its juice is used in the treatment of earache, jaundice, fever and bladder disease. The fruit and other aerial parts are used in the treatment of boils, sores, cuts, constipation, intestinal and digestive problems [9], and used as antimutagenic, anticoagulant, antispasmodic, antileukemia agents [10]. In vivo antitumor activity was demonstrated in mice [11]. The plant is used as anti-inflammatory, antispasmodic, and its fruit is used as food [10]. In tropical Africa, the fruit is eaten as snack, and the leaves are eaten as a salad [12]. In the study area,it grows widely andthe 
inhabitants use it as a source of vegetable without the proper knowledge of its nutritional value. Such study could help in the understanding of its potential as a source of nutrients food for man and livestock. The aim of this research is to evaluate the nutritional potential of $P$. angulata as a source of nutrients that could be useful in alleviating nutrient deficiency.

\section{Materials and Methods}

\subsection{Collection and Preparation of Plant Materials}

Fresh leaf and fruit of Physalis angulata (L) were collected in the month of August, 2011 from the surrounding of Zuru road, Wamako Local Government, and the areas of Jumu'at Mosque of the Usmanu Danfodiyo University, Sokoto, Nigeria. It was identified and authenticated in the Herbarium of the Department of Biological Sciences (Botany Unit), Usmanu Danfodiyo University, Sokoto, where a voucher specimen was prepared and deposited. The leaf and fruit were sun dried and separately pulverized into powder and kept in the laboratory at room temperature for the analysis. The following were determined in the laboratory; proximate analysis of the leaves and fruits, amino acids content, anti-nutrient and trace mineral elements.

\subsection{Proximate and Mineral Analysis}

The air dried samples were analyzed in triplicate for proximate composition in accordance with the Official Methods of the Association of Official Analytical Chemists (AOAC) [13]. Ash was determined by incinerating two grams $(2 \mathrm{~g})$ at $550^{\circ} \mathrm{C}$ in lent on furnaces (England) over night. Fibre was determined by drying two gram $(2 \mathrm{~g})$ of grounded dried over night at $105^{\circ} \mathrm{C}$ in the oven (Gallenhamp Oven BS) and incinerated at $550^{\circ} \mathrm{C}$ for 90 minutes in lent on furnaces (England). Moisture Content was determined by drying two gram $(2 \mathrm{~g})$ of powdered plant materials overnight at $105^{\circ} \mathrm{C}$ in the oven (Gallenhamp Oven BS). Crude lipid was determined using saturation method. Two grams $(2 \mathrm{~g})$ of ground dried materials were weighed into $50 \mathrm{ml}$ conical flask and n-hexane was added and allowed to stand at room temperature overnight. It was drained into an empty flask, earlier weighed and designated $\mathrm{W}_{1}$. It was placed in an oven to allow the n-hexane to evaporate in the oven (Gallenhamp Oven BS). Protein ( $\% \mathrm{~N}$ x 6.25) was determined by the Micro-Kjeldahl Method and soluble carbohydrate was determined as the difference between crude protein and the sum of ash, protein, crude lipid and crude fibre.

\subsection{Mineral and Antinutritional Analysis}

Analysis of minerals was done in triplicate according to methods as described in $[14,15]$. The investigated minerals include phosphorus, potassium, sodium, calcium, and magnesium. Phosphorus was determined using Spectrophotometer (JENWAY 6100) at $660 \gamma$ (wavelength), Potassium and sodium was determined using flame photometer (Corning 400 Essex. England), while that of calcium and magnesium was done by ethylene diamine tetra acetic acid (EDTA) titration method. Oxalate was determined by the method of Krishna and Ranjhan [16,] while, phytate and hydrocyanic acid were determined by the AOAC [17] method and nitrate was determined by IITA method [14]. Metal analysis (except sodium and potassium) was done using Atomic Absorption Spectroscopy (AAS).

\subsection{Amino Acid Analysis}

The amino acid content was determined using methods described by Spackman [15]. The samples were dried to constant weight, defatted, hydrolysed and analysed using sequential Multi-sample Amino Acid Analyzer (TSM). The samples were defatted by weighing a known weight of the dried sample into extraction thimble and the fat was extracted with chloroform/methanol (2:1 mixture) using soxhlet extraction apparatus and nitrogen was determined using MicroKjedhal methods ${ }^{20}$. The samples were hydrolyzed by weighing the defatted sample into glass ampoule and seven millilitres $(7 \mathrm{ml})$ of $6 \mathrm{~N} \mathrm{HCl}$ was added and oxygen was expelled by passing nitrogen into the ampoule. The glass ampoule was sealed with Bunsen burner flame and put in an oven preset at $105^{\circ} \mathrm{C}$ for 22 hours and the content was filtered to remove the humins. The filtrate was evaporated to dryness at $40{ }^{\circ} \mathrm{C}$ under vacuum in a rotary evaporator and the residue was dissolved with $5 \mathrm{ml}$ of acetate buffer ( $\mathrm{pH} 2.0$ ) and stored in plastic bottles and kept in freezer. The hydrolysate was loaded into the TSM Analyzer by loading 5 to 10 micro litres ( 5 for acidic/ neutral amino acid and 10 for basic amino acids). This was dispensed into the cartridge of the analyzer. The TSM analyzer is designed to separate and analyze free acidic, neutral and basic amino acids of the hydrolysate which lasted for 76 minutes. Data obtained was statistically analysed using T-test method of analysis, with SPSS version 16.0 and result reported as mean \pm standard error of means of triplicate values in each case.

\section{Results}

The result of proximate analysis of $P$. angulata is presented in Table 1 witha protein content of 27.80 and $10.97 \%$ in fruit and leaf respectively. The crude fibre content was high (10.97\%) for the leaves and the fruits had (1.83\%). The lipids was $3.67 \%$ for the leaf and $2.33 \%$ for the fruit, ash was $15.33 \%$ for the leaf and fruit had $8.33 \%$, while carbohydrate had $66.36 \%$ for the leaf and $59.70 \%$ for the fruit respectively. Lipids, ash and carbohydrate are within the range expected for dry leafy vegetables as shown in Table 1 . The results shows high significance difference $(\mathrm{p}<$ 0.05 ) in all parameters except in moisture content where there is no significance difference between the moisture 
content in the leaves and that of the fruits as indicated in the Table 1.Table 2 present the mineral concentrations in the leaves and fruits of $P$. angulate with $\mathrm{Cu}$ content of 3.01 and $30.33 \mathrm{mg} / \mathrm{kg}$ in the leaf and fruit respectively. Mn had 21.60 $\mathrm{mg} / \mathrm{kg}$ content in leaf and $19.53 \mathrm{mg} / \mathrm{kg}$ in fruit, $\mathrm{Fe}$ had the mean concentration of $3.22 \mathrm{mg} / \mathrm{kg}$ in leaf and $2.03 \mathrm{mg} / \mathrm{kg}$ content for the fruit, $\mathrm{Pb}$ had the mean values of $0.97 \mathrm{mg} / \mathrm{kg}$ in leaves and $0.60 \mathrm{mg} / \mathrm{kg}$ for the fruits, $\mathrm{Cr}$ had the mean concentration of $2.50 \mathrm{mg} / \mathrm{kg}$ content in leaf and $1.53 \mathrm{mg} / \mathrm{kg}$ content in fruit, $\mathrm{Zn}$ had mean values of $0.20 \mathrm{mg} / \mathrm{kg}$ for the leaf and $1.30 \mathrm{mg} / \mathrm{kg}$ for the fruit, while $\mathrm{Cd}$ had the mean concentration of $0.13 \mathrm{mg} / \mathrm{kg}$ for the leaf and $0.07 \mathrm{mg} / \mathrm{kg}$ for the fruit respectively. There is no significance difference $(\mathrm{p}<$ 0.05 ) in cadmium and potassium content between the leaf and fruit.

Table 3 shows the result of anti-nutrient analysis, and phytate had the highest proportion in leaf and fruit with 6.91 and $8.59 \mathrm{mg} / 100 \mathrm{~g}$ respectively. Oxalate content in leaf and fruit was $(2.03$ and $1.02 \mathrm{mg} / 100 \mathrm{~g})$, followed by the tannins with 2.74 and $3.21 \mathrm{mg} / 100 \mathrm{~g}$ in leaf and fruit respectively. The result of the $\mathrm{T}-$ test, showed significance difference $(\mathrm{p}<$ 0.05 ) in the contents of the phytate, oxalate and tannins in leaf and fruit. There is no significance difference in the nitrate content between the leaf and fruit (Table 3).

Table 1. Proximate composition of the leaf and fruit of $P$. angulata (g/100g, dry weight)

\begin{tabular}{|c|c|c|c|}
\hline Parameters & Leaf & Fruit & $\begin{array}{c}(\mathrm{p}<0.05) \text { level of } \\
\text { significance }\end{array}$ \\
\hline Moisture (\%) & $3.83 \pm 0.12$ & $3.83 \pm 0.01$ & 0.76 \\
\hline $\begin{array}{c}\text { Ash content } \\
\text { (\%) }\end{array}$ & $8.33 \pm 0.12$ & $15.33 \pm 0.01$ & 0.00 \\
\hline $\begin{array}{c}\text { Lipids (fats) } \\
\text { (\%) }\end{array}$ & $2.33 \pm 0.02$ & $3.66 \pm 0.01$ & 0.00 \\
\hline $\begin{array}{c}\text { Crude fibre } \\
\text { (\%) }\end{array}$ & $1.83 \pm 0.04$ & $10.97 \pm 0.01$ & 0.00 \\
\hline $\begin{array}{c}\text { Crude protein } \\
\text { (\%) }\end{array}$ & $27.80 \pm 0.01$ & $10.97 \pm 0.01$ & 0.00 \\
\hline $\begin{array}{c}\text { Carbohydrate } \\
(\%)\end{array}$ & $59.70 \pm 0.07$ & $66.36 \pm 0.01$ & 0.00 \\
\hline
\end{tabular}

The data are mean \pm values of SD for three replications.

Table 4 shows the amino acids content in leaf and fruit of $P$. angulata. Seventeen amino acids were found in varying proportions in leaf and fruit. All the essential amino acids were present in leaf and fruit. Phenylalanine + tyrosine had the highest value of $6.38 \mathrm{~g} / 100 \mathrm{~g}$ in leaf and $5.22 \mathrm{~g} / 100 \mathrm{~g}$ in fruit, lysine content in leaf was $4.16 \mathrm{~g} / 100 \mathrm{~g}$ and $3.09 \mathrm{~g} / 100 \mathrm{~g}$ in fruit, valine had $4.36 \mathrm{~g} / 100 \mathrm{~g}$ in leaf and $2.50 \mathrm{~g} / 100 \mathrm{~g}$ for the fruit respectively. Isoleucine contents in leaf was 3.04 $\mathrm{g} / 100 \mathrm{~g}$ and $2.01 \mathrm{~g} / 100 \mathrm{~g}$ in fruit, threonine contents 3.25 $\mathrm{g} / 100 \mathrm{~g}$ in leaf and $2.50 \mathrm{~g} / 100 \mathrm{~g}$ in the fruit, histidine contents in leaf was $2.29 \mathrm{~g} / 100 \mathrm{~g}$ and $1.60 \mathrm{~g} / 100 \mathrm{~g}$ in fruit, methionine + cysteine had $2.07 \mathrm{~g} / 100 \mathrm{~g}$ contents in leaf and $1.23 \mathrm{~g} / 100 \mathrm{~g}$ contents for the fruit, while the limiting amino acids is the leucine with $0.25 \mathrm{~g} / 100 \mathrm{~g}$ contents in leaf and $5.16 \mathrm{~g} / 100 \mathrm{~g}$ for the fruit. The proportions of the essential amino acids in leaf and fruit were compared with the WHO ideal protein standard as shown in Table 2. For the non - essential amino acids glutamic acid had the highest proportion of 11.62 $\mathrm{g} / 100 \mathrm{~g}$ content in leaf and $6.26 \mathrm{~g} / 100 \mathrm{~g}$ content for the fruit, aspartic acid came second with $7.73 \mathrm{~g} / 100 \mathrm{~g}$ content in leaf and $4.36 \mathrm{~g} / 100 \mathrm{~g}$ for the fruit. Arginine content in leaf was $4.51 \mathrm{~g} / 100 \mathrm{~g}$ and $3.23 \mathrm{~g} / 100 \mathrm{~g}$ for the fruit, alanine had 4.09 $\mathrm{g} / 100 \mathrm{~g}$ contents in leaf and $2.90 \mathrm{~g} / 100 \mathrm{~g}$ contents in the fruit, glycine contents in leaf was $3.45 \mathrm{~g} / 100 \mathrm{~g}$ and $3.23 \mathrm{~g} / 100 \mathrm{~g}$ for the fruit. Serine had $2.29 \mathrm{~g} / 100 \mathrm{~g}$ for the leaf and $3.10 \mathrm{~g} / 100 \mathrm{~g}$ in fruit, while proline had $2.34 \mathrm{~g} / 100 \mathrm{~g}$ contents in leaf and $2.12 \mathrm{~g} / 100 \mathrm{~g}$ contents in fruit respectively.

Table 2. Mineral Concentrations of the leaf and fruit of $P$. angulata (mg/kg DW)

\begin{tabular}{|c|c|c|c|}
\hline Mineral element & Leaf & Fruit & $\begin{array}{c}(\mathrm{P}<0.05) \\
\text { Level of } \\
\text { Significance }\end{array}$ \\
\hline Copper $(\mathrm{Cu})$ & $3.01 \pm 0.03$ & $30.33 \pm 0.23$ & 0.00 \\
\hline Iron $(\mathrm{Fe})$ & $3.22 \pm 0.01$ & $2.03 \pm 0.01$ & 0.00 \\
\hline Manganese $(\mathrm{Mn})$ & $21.60 \pm 0.10$ & $19.53 \pm 0.01$ & 0.01 \\
\hline Cadmium $(\mathrm{Cd})$ & $0.13 \pm 0.15$ & $0.07 \pm 0.02$ & 0.52 \\
\hline Lead $(\mathrm{Pb})$ & $0.97 \pm 0.01$ & $0.60 \pm 0.10$ & 0.00 \\
\hline Chromium $(\mathrm{Cr})$ & $2.50 \pm 0.10$ & $1.53 \pm 0.01$ & 0.00 \\
\hline Sodium $(\mathrm{Na})$ & $186.67 \pm$ & $689.48 \pm$ & 0.00 \\
\hline Potassium $(\mathrm{K})$ & $3.01 \pm 0.03$ & $30.33 \pm 0.23$ & 0.42 \\
\hline Calcium $(\mathrm{Ca})$ & $0.42 \pm 0.03$ & $0.47 \pm 0.03$ & 0.10 \\
\hline Magnesium $(\mathrm{Mg})$ & $1.37 \pm 0.06$ & $2.08 \pm 0.12$ & 0.00 \\
\hline Phosphorus $(\mathrm{P})$ & $3.01 \pm 0.03$ & $30.33 \pm 0.23$ & 0.00 \\
\hline Zinc $(\mathrm{Zn})$ & $1.30 \pm 0.10$ & $0.20 \pm 0.10$ & 0.00 \\
\hline
\end{tabular}

The data are mean value \pm standard error of three replicates. DW $=$ dry weight

Table 3. Antinutritional contents of the leaf and fruit of $P$. angulata $(\mathrm{mg} / 100 \mathrm{~g})$

\begin{tabular}{|c|c|c|c|}
\hline Antinutrient & Leaf & Fruit & $\begin{array}{c}(\mathrm{P}<0.05) \text { level of } \\
\text { significance }\end{array}$ \\
\hline Phytic acid & $\begin{array}{c}6.91 \pm \\
0.65\end{array}$ & $8.59 \pm 0.64$ & 0.03 \\
\hline Tannins & $\begin{array}{c}2.03 \pm \\
0.04\end{array}$ & $1.04 \pm 0.02$ & 0.00 \\
\hline Oxalates & $\begin{array}{c}2.74 \pm \\
0.47\end{array}$ & $3.21 \pm 0.34$ & 0.00 \\
\hline Nitrate & $\begin{array}{c}0.05 \pm \\
0.06\end{array}$ & $\begin{array}{c}0.11 \pm \\
0.00\end{array}$ & 0.19 \\
\hline
\end{tabular}

The data are mean \pm SD of three replicates.

Table 5. Anti-nutrients to Nutrients Molar Ratio

\begin{tabular}{|c|c|c|c|}
\hline $\begin{array}{c}\text { Anti-nutrients to Nutrients } \\
\text { Ratio }\end{array}$ & Leaves & Fruits & $\begin{array}{c}\text { Critical } \\
\text { level* }\end{array}$ \\
\hline [Oxalate] / [Ca] & 6.52 & 6.82 & 2.5 \\
\hline$[$ Oxalate] / [Ca $+\mathrm{Mg}]$ & 1.53 & 0.79 & 2.5 \\
\hline$[\mathrm{Ca}][$ Phytate] / [Zn] & 2.33 & 20.19 & 0.5 \\
\hline$[$ Phytate] / [Ca] & 16.45 & 18.28 & 0.2 \\
\hline$[$ Phytate] / [Fe] & 2.15 & 4.23 & 0.4 \\
\hline$[$ Phytate] / [Zn] & 5.32 & 42.95 & 10 \\
\hline
\end{tabular}


Table 4. Amino acid content of leaf and fruit of P. angulata compared to the WHO "ideal protein" standard (g/100g protein).

\begin{tabular}{|c|c|c|c|}
\hline Amino acid & Leaf & Fruit & $\begin{array}{c}\text { WHO Ideal } \\
\text { Protein }\end{array}$ \\
\hline Lysine & $4.16(1.07)$ & 3.09 & 5.8 \\
\hline Leucine & $0.25(-4.91)$ & 5.16 & 6.6 \\
\hline Isoleucine & $3.04(1.03)$ & 2.01 & 2.8 \\
\hline Threonine & $3.25(1.00)$ & 2.25 & 3.4 \\
\hline Valine & $4.36(1.86)$ & 2.50 & 3.5 \\
\hline $\begin{array}{c}\text { Methionine }+ \\
\text { cysteine }\end{array}$ & $2.07(0.84)$ & 1.23 & 2.5 \\
\hline $\begin{array}{c}\text { Phenylalanine }+ \\
\text { Tyrosine }\end{array}$ & $6.38(1.16)$ & 5.22 & 6.3 \\
\hline Histidine & $2.29(0.69)$ & 1.60 & - \\
\hline Arginine & $4.51(1.28)$ & 3.23 & - \\
\hline Aspartic acid & $7.73(3.37)$ & 4.36 & - \\
\hline Serine & $2.29(-0.81)$ & 3.10 & - \\
\hline Glutamic acid & $11.62(5.36)$ & 6.26 & - \\
\hline Proline & $2.34(0.22)$ & 2.12 & - \\
\hline Glycine & $3.45(0.41)$ & 3.04 & - \\
\hline Alanine & $4.09(1.19)$ & 2.90 & - \\
\hline
\end{tabular}

\section{Discussion}

The moisture content in the samples analysed like other leafy vegetables was low with $8.33 \pm 0.12 \%$ in leaf and 3.83 $\pm 0.01 \%$ for the fruit. These values were low when compared with that of sweet potato (Ipomea batatas) leaf with $83.7 \%$ $87.1 \%$ [16], [17]. Both the fruit and the leaf generally had high ash content $15.33 \pm 0.01 \%$ fruit $),(8.33 \pm 0.12 \%$ leaf $)$. The crude protein in the entire samples was relatively high, ranging from $(27.80 \pm 0.01 \%$ leaf) and $(10.97 \pm 0.01$ fruit). The values are among the highest reported in leafy vegetables when compared to the reported values for some wild leafy vegetables such as Momordica balsamina (11.29 $\pm 0.07 \%)$, Moringa oleifera (20.72\%), Lesianthera africana $(13.10-14.90 \%)$ and Leptadenia hastata $(19.10 \%)$, [18], [19], [20], [21]. The protein recommended dietary allowance (RDA) for both Men and Women is $0.80 \mathrm{~g}$ of good quality protein $/ \mathrm{kg}$ body weight $/ \mathrm{d}$ [22]. The crude lipids were $(2.33 \pm 0.02 \%$ in leaf), $(3.66 \pm 0.01 \%$ for fruit $)$, these values are within the range as reported for some wild green leafy vegetables in Nigeria and Republic of Niger [19]. Low lipid content is probably the factor considered for recommending leafy vegetables in controlling overweight. The analyses leafy vegetables have crude fibre contents in the following order $(10.97 \pm 0.01 \%$ fruit $)$ and $(1.83 \pm 0.04 \%$ leaf $)$, the values are high when compared with $3.7 \%$ found in Ipomea batatas leaf [16]. The carbohydrate was $59.70 \%$ for the leaf and $66.36 \%$ for the fruit), these value is within the range expected for dry leafy vegetables as reported for some wild leafy vegetables [24].

Seventeen amino acids were found in varying proportions; all the essential amino acids were present with few exceptions. The proportions of the amino acids present were compared with WHO ideal protein standard. Phenylalanine + Tyrosine rank $100 \%$ in comparison to the WHO standard. Valine and Lysine also had high scores of $95 \%$ and $97 \%$ respectively. Threonine, Leucine, Tyrosine and Methionine + Cysteine in both leaf and fruit rank below $50 \%$. These results also support the claim that the protein in leafy vegetables although low, is of a very high grade [25].

Tannins decrease protein quality by reducing digestibility and palatability; it also causes damage to the intestinal tract, interference with the absorption of iron and a possible carcinogenic effect [26]. Generally, high phytate and oxalate content in vegetables indicate that consumption of these leaves could decrease the bioavailability of minerals, especially, $\mathrm{Mg}, \mathrm{Ca}$, and $\mathrm{Zn}$ [27]. The amount of phytate, oxalate, tannin and nitrate in the leaf and fruit reported herein is well below the range that would adversely affect nutritional values or cause any toxic effects associated with anti nutrients. Protein and starch solubility, digestion and absorption were found to be affected by phytate [28].

The mineral profile of the leafy vegetables analyzed indicated that potassium content had $(30.33 \mathrm{mg} / 100 \mathrm{~g} \mathrm{DW})$. These values were low when compared with that reported for Ipomea batatas leaf $(750-4,953.49 \mathrm{mg} / 100 \mathrm{~g}$ dry weight $)$ [17], [29], [30]. The values were low compared to Celosia argentea $(5,200 \mathrm{mg} / 100 \mathrm{~g})$, Solanum aethiopicum $(5,000$ $\mathrm{mg} / 100 \mathrm{~g})$ and Talinum triangulare $(8,000 \mathrm{mg} / 100 \mathrm{~g})$ [31]. Sodium content in fruit $(689.48 \mathrm{mg} / 100 \mathrm{~g})$ was high when compared with the values reported in Talinum triangulare (248.8 - $280 \mathrm{mg} / 100 \mathrm{~g}$ [32], [31]. Calcium and phosphorus were associated with each other for development and proper functioning of bones, teeth and muscles [33], [34]. The respective calcium and phosphorus contents ( $\mathrm{mg} / 100 \mathrm{~g} \mathrm{DW})$ in the vegetables was $(0.47 \mathrm{mg} / 100 \mathrm{~g}$ in leaf) and $(30.33$ $\mathrm{mg} / 100 \mathrm{~g}$ in fruit). The calcium content in the leaf was generally low compared with $226.4-11.775 .3 \mathrm{mg} / 100 \mathrm{~g}$ reported in some wild leafy vegetables of south eastern Niger Republic [35] and Ipomea batatas leaf $(9,300-19,300 ; 170$ $-220 \mathrm{mg} / 100 \mathrm{~g}$ ) reported by [32]. The phosphorus content was lower than that found in Indian Solanum tubirosam leaf $(237 \mathrm{mg} / 100 \mathrm{~g})$ and Solanum americanum $(130.46 \mathrm{mg} / 100 \mathrm{~g})$ [36]. The leaf and fruit contained potentially useful quantities of many essential minerals and trace elements including cadmium $(\mathrm{Cd}) 0.05 \mathrm{mg} / \mathrm{kg}$, zinc $(\mathrm{Zn}) 0.20 \mathrm{mg} / \mathrm{kg}$, copper $(\mathrm{Cu}) 3.01 \mathrm{mg} / \mathrm{kg}$, lead $(\mathrm{Pb}) 0.97 \mathrm{mg} / \mathrm{kg}$, chromium $(\mathrm{Cr})$ $2.50 \mathrm{mg} / \mathrm{kg}$ and manganese $(\mathrm{Mn}) 21.60 \mathrm{mg} / \mathrm{kg}$. Cadmium is the non - essential element in foods and natural water and it accumulates principally in the kidneys and liver [37]. According to FAO / WHO [38], the safe limit for cadmium consumption in vegetables is $0.2 \mathrm{mg} / \mathrm{kg}$. The content of both cadmium and zinc reported in this study is generally lower than the permissible levels by FAO / WHO in vegetables. Among all heavy metals, zinc is the least toxic and is an essential element in human diet as it required for maintaining the functioning of the immune system [39]. Zinc deficiency in the diet may be highly detrimental to human diet. Lead is a 
serious cumulative body poison which enters into the body system through air, water and food and cannot be remove by washing fruits and vegetables [40].

Many people in urban areas consider wild foods as poor man's food or famine food, especially the youth, who consider junk food as superior. The result presented herein indicated that the edible wild leafy vegetable analysed have a great potential as a source of food particularly considering it is protein and amino acid profile, which can be used in narrowing the amino acid and other nutrients supply deficits that are prevalent in many developing countries. In addition, considering the ash contents, this indicates that it is good source of important mineral needed by the body. The mineral content of $P$. angulata, indicate that it is rich in most mineral elements required by the body for normal growth and development.

\section{REFERENCES}

[1] WHO, (1992). Cadmium, Environmental Health Criteria, Geneva. 134.

[2] Weingartner, L. (2004). The Food and Nutrition Security Situation at the Beginning of the Millennium. Background paper no. II. International training course on food and nutrition security assessment instrument and intervention strategies. Deutsche Gesellschaft Fur Technische Zusammenarbeit $\mathrm{GmbH}$.

[3] Vainio - Maltila, K. (2000). Wild Vegetables used by the Sambaa in the Usambara Mountains, North Eastern of Tanzania. Annals of Botany Fennici.37: 57-98.

[4] Weinberger, K. and Swai, I. (2006). Consumption of Traditional Vegetables in Central and Northern Tanzania. Ecology of Food and Nutrition.45: 87 - 103.

[5] Ganry, J. (2008). Promotion of Fruits and Vegetables in Countries of Sub Saharan Africa and Indian Ocean. Fruits.63: 63.

[6] WHO, (2003). Diabetes Cases Could Double in Developing Countries in next 30 years. In: Weinberger, L. (2004). The Food and Nutrition Security Situation at the Beginning of the Millennium. Background paper no. II. International Training Course on Food and Nutrition Security Assessment Instruments and Intervention Strategies. Deutsche Gesellschaft fur technische Zusammenarbeirt GmbH.

[7] Nnamani, C. V., Oselebe, H. O., Okporie, E. O. (2007). Ethnobotany of Indigenous Leafy Vegetables of Izzi Clan in Ebonyi State, Nigeria. In: proceeding of $20^{\text {th }}$ Annual National Conference of Biotechnology Society of Nigeria. Abakaliki, November $14^{\text {th }}-17^{\text {th }}$. PP. $111-114$.

[8] Adebooye, O. C. and Opabode, J. T. (2004). Status of Conservation of the Indigenous leaf Vegetables and Fruits of Africa. African Journal of Biotechnology. 3(12): 700 - 705

[9] Sultana, N., Hassan, M. A. and Mahabuba, S. (2008). Heavy Metal Analysis in Some Selected Wild Leafy Vegetables in Northern Iran. Journal of Food Science and Nutrition. 8(2): 141-146.
[10] Freitas, T. de A., Rodrigues, A. C. da C., Osuna, J. T. A. (2006). Cultivation of Physalis angulata (L) and Andenanthera colubrina [(Bell) Brenan] species of the Brazilian semi arid. Feira de Santana State University, Department of Biological Sciences Brazil.,44100 - 000

[11] Malgalhaes, P. M., Bilia, A. R., Bergonzi, M. C., Vincieri, F. F. (2006). Simultaneous Analysis of Artemisinin and Flavonoids of Several Extracts of Artemisia annua (L), Obtained from Commercial Sample and a Selected Cultivar. Journal of Phytomedicine, 13(7): 487-493.

[12] Mairura, F. S. (2008). Physalis angulata L. [Internet] Record from Protabase. Schmelzer, G. H. \& Gurib - Fakim, A. (Editors). PROTA (Plant Resources of Tropical Africa / Ressources vegetales de l'Afrique tropicale), Wageningen, Netherlands. $<$ http://database.prota.org/search.htm>. Access ed 12 May, 2011.

[13] AOAC (1995). Official Methods of analysis Association of official Analytical Chemists. Washington DC, U. S. A.

[14] IITA (1988). Selected Methods of Soil Chemical Analysis. Sixth Printing Washington D. C. Publishing, USA. PP. $108-$ 110 .

[15] Spackman, D. H., Stein, E. H. and Moore, S. (1958). Automatic Recording Apparatus for Use in the Chromatography of amino acids. Analytical chemestry. 30: 1191.

[16] Asibey - Berko, E. and Tayie, F. A. K. (1999). Proximate Analysis of Some Underutilized Ghanian Vegetables. Ghana Journal of Science. 39: 91 - 92.

[17] Ishida, H., Suzuno, H., Sugiyama, N., Innami, S., Todokoro, T. and Maekawa, A. (2000). Nutritional Evaluation of Chemical Components of Leaves Stalks and Stems of Sweet Potatoes (Ipomea batatas). Food Chemistry. 68: 359 - 367.

[18] Isong, E. U. and Idiong, U. I. (1997). Comparative Study on the Nutritional and Toxic Composition of three varieties of Lesianthera Africana. Plant Foods for Human Nutrition.51: $79-84$.

[19] Sena, L., Vanderjagt, D., Rivera, C., A., Muhamadou, O., Milson, M., Pastosyn, A. and Glew, R. (1998). Nutritional Profile from Wild Edible Plants from Mexico. Plant Food Human Nutrition.52: 17-30.

[20] Lockeett, C. T., C. C. and Grivetti, L. E. (2000). Energy and micronutrient composition of dietary and medicinal wild plants consumed during drought: Study of rural Fulani, Northeastern Nigeria. International Journal of Food Sciences and Nutrition. 51(2): $77-82$.

[21] Hassan, L. G. and Umar, K. J. (2006a). Nutritional Value of Baslam Apple (Momordica balsamina L.) Leaves. Pakistan Journal of Nutrition. 5(6): 522 - 529.

[22] FND (2002). Food and Nutrition Board, Institute of Medicine. National Academy of Sciences. Dietary Reference Intake for Energy, Carbohydrate, Fibre, Fat, Fatty Acids, Cholesterol, Protein and Amino Acid (Micro Nutrients). www.nap.edu. (Retrieved on 14/5/2010).

[23] Ifon , E. T. Bassir, O. (1980). The Nutritive Value of Some Nigerian Leafy Green Vegetables - Part 2: the Distribution of Protein, Cabohydrates (including ethanol - soluble simple sugars), Crude Fat, Fibre and Ash. Food Chemistry 5: $231-$ 
235.

[24] Osagie, A. U., Offiong, (1998). Nutrional Quality of Plant Food. Ambik Press, Benin city, Edo State, Nigeria. PP. 131221.

[25] Okaka, J. C., Akobundu, E. N. T. and Okaka, N. C. (2000). Human Nutrition and Integrated Approach, $2^{\text {nd }}$ Edition, Janco, O. C. Academic Publishers. Enugu, Nigeria. PP. 1 - 6.

[26] Butler, L. G. (1989). Effects of Condensed Tannin on Animal Nutrition, In: "Chemistry and Significance of Condensed Tannin" Hemmingway R. W. Karehesy, J. J. Edition Plenum Press New York, U. S. A. PP. 391 - 402.

[27] Bhandari, M. R. and Kawabata, J. (2004). Assessment of Anti nutritional Factors and Bioavailability of Calcium and Zinc in Wild Yam (Dioscorea spp) Tubers of Nepal. Food Chemistry. 85: $281-287$.

[28] Agte, V. V., Tarwadi, K. V. and Chiplonkar, S. A. (1999). Phytate Degradation During Traditional Cooking: Significance of the Phytic Acid Profile in Cereal - Based Vegetarian Meals. Journal of Food Composition and Analysis. 12: 161 - 167.

[29] Tayie, F. A. K. and Asibey - Berko, E. (2001). Mineral Contents of Some Indigenous Vegetables of Ghana. Ghana Journal of Science.41: 49 - 54.

[30] Monamodi, E. L., Bok, I., and Karikari, S. K. (2003). Changes in Nutritional Composition and Yield of Two Sweet Potato (Ipomea batatas L.) Cultivars during their Growth in Botswana. UNISWA Journal of Agriculture. 11:5 - 14.

[31] Smith, I. F. Leafy Vegetables as Sources of Minerals in Southern Nigerian Diets. Nutritional Report International. 1982. 26: $679-688$.

[32] Ifon, E. T. and Bassir, O. (1979). The nutritive value of some Nigerian leafy green vegetables - part 1: Vitamin and Mineral Contents. Food Chemistry. 4: $263-267$.
[33] Dosunmu, M. I. (1997). Chemical composition of the fruit of Tetrapleura tetreptera and the physico-chemical properties of it is oil. Global Journal of Pure and Applied Sciences 3(1): 61 -67 .

[34] Turan, M., Kordali, S., Zengin, H., Dursun, A. and Sezen, Y. (2003). Macro and Micro Mineral Content of Some Wild Edible Leaves Consumed in Eastern Anatolia. Acta Agriculture Scandinavica, Section B, Plant Soil Science.53: $129-137$.

[35] Humphry, C. M., Clegg, M. S. Keen, C. L. and Grivetti, L. E. (1993). Food Diversity and Drought Survival. The Hausa example. International Journal of Food Sciences and Nutrition. 44(1): $1-6$.

[36] Hassan, L. G. and Umar, K. J. (2008). Nutritional Value of Nightshade (Solanum americanum L.) Leaves. Electronic Journal of Food and Plants Chemistry. 3(1): 14-17.

[37] Divrikli, U., Horzum, N., Soylak, M., and Elci, L. (2006). Trace Heavy Metal Contents of Some Spices and Herbal Plants from Western Anatolia, Turkey. International Journal of Food Sience and Technology.41: 712 - 716.

[38] FAO/WHO. United Nation Food and Agriculture Organization/World Health Organization: Fruits and Vegetables for Health. Report of a joint FAO/WHO workshop, 1-3 September Kobe, Japan, 2004. Available at: $\mathrm{http} / \mathrm{www}$. Who.int/dietphysicalactivity/fruits/en/index 1.html Accessed November $10^{\text {th }}, 2005$.

[39] Ladipo, M. K. and Doherty, V. F. (2011). Heavy Metal Levels in Vegetables from Selected Markets in Lagos, Nigeria. African Journal of Food Science and Technology. 2(1): 18 21.

[40] Divrikli. U., Saracoglu. S. Soylak. M. and Elci. L. (2003). Determination of Trace Heavy Metal Contents of Green Vegetables Samples from Kayseri- Turkey by Flame Atomic Absorption Spectrometry. Fresenius Environ. Bull. 12: $1123-1125$ 